\title{
The Variety of The Entrance Changes of Rumah Gadang Minangkabau
}

\author{
Rosalinda Wiemar \\ Universitas Trisakti \\ Jakarta, Indonesia rosalindawiemar@gmail.com
}

\begin{abstract}
Rumah gadang Minangkabau is a traditional house owned by one clan. The activities within the rumah gadang are numerous and varied. Especially because occupied by several families. Circulation of the occupants from and into the home is very important, entrances is the main facility in the circulation. The development of technology and information globally affect the social life of the occupants, which affects the activities and circulation in the rumah gadang. The purpose of the study is to observe how the entrance changes of the rumah gadang and its causes factors. With the method of qualitative naturalistic research conducted observation of two rumah gadang with its people and environment. The result of the analysis shows that basically there is a link between the changes in socio culture of the occupants with the changes of entrances at the rumah gadang. From the research resulted data of praxis and academic knowledge.
\end{abstract}

Keywords: rumah gadang, variation, change, entrance

\section{INTRODUCTION}

Minangkabau are an ethnic group originating from West Sumatra. This ethnic group has high art and culture. One of them is the art of traditional house called rumah gadang (big house). Rumah gadang is a house that is inherited from generation to generation by a clan. There are several forms of rumah gadang, but what will be discussed in this study is Gajah Maharam house. The rumah gadang is inhabited by several family heads, the activities carried out inside the gadang house are very much and varied, for this reason the circulation facilities in the rumah gadang are very important. The rapid development of technology and information affects society in general, residents of the rumah gadang in particular. Changes in occupant activities affect the need for facilities at rumah gadang. The main entrance of rumah gadang also indirectly experienced changes. The door is an opening in the wall / residential area, in general there are several doors in one house, which will be discussed in this research is the main door of rumah gadang. The main door originally functioned as a means of circulation for residents, but at this time, the main function of the door was changed. Information and new technologies are very difficult to filter, some are negative and positive. In order for the change in rumah gadang to have no negative impact, it is necessary to know the form and customs of rumah gadang at first, the changes that occur and what causes, so that it can be known which changes have positive and negative impacts.

\section{LITERATURE REVIEW}

House is a private living space of someone or many people, usually a family. Residents will feel that they have a personal space and area that is truly personal, without any interference from other people including neighbors (Prawitasari, 1989).

Sarlito, 1989, states that home is one of the main places for humans to interact socially: forming and holding a family, accepting friends and relationships, showing their social status. The establishment of a rumah gadang for a large family, besides being a sign of the existence of a people, also as a shelter, for family members who have not been able to make their own homes.
In a house, there are openings commonly referred to as windows, doors, skylights and ventilation. The door as the main facility in circulation, is always in every rumah gadang. In the Indonesian Dictionary, definition of the door is a place to enter and exit. Means that the door is a connecting object to enter into something or get out of a place. If it is associated with a residence, definition of the door is a place to enter and out of the human residence. Technology, industry, contact with other cultures directly or through various media, not only has a positive impact, but also the negative impact. According to Ogburn in Sayogyo (1985: 119204) there are two factors that influence social change, which will indirectly affect traditional culture, namely: 1. The causes that originate in the community itself (Endogenous) include:

a. Increasing / decreasing population. b. New discoveries. c. Conflict. d. Revolution. 2. Causes from outside (Exogen), including: a. Natural disasters (earthquake, typhoon, big flood and others). b. War. c. Cultural influences of other communities. In addition, in a society where there is a process of change, there will be factors that encourage and hold back the process of change, namely: 1. Factors that encourage, such as: the presence of other cultural contacts, an increasingly advanced formal and informal education system, the heterogeneous population, the dissatisfaction of society with certain aspects of life, orientation in the future, disorganization in society and and the ease of accepting new things. 2. Blocking factors include: there is a lack of relations with other communities, traditional attitude towards the community, a deeply embedded interest, fear of interference in cultural integration, a closed attitude, ideological, customary or cultural barriers and values that assume that life is essentially bad and it can't be fixed.

\section{PROBLEM STATEMENTS}

Rumah Gadang is a Minangkabau clan house, this house is built with various functions and requirements in its construction. As a tool in customary, rumah gadang is more concerned with the main function as a shelter and a place to carry out ceremonial / custom activities in a clan. 
The inclusion of technology and information led to an increase in the needs of the population, which also affected changes in the existing facilities in rumah gadang. Some changes have been made to several building elements, both in space and inside the house, one of it, is at the entrance. Technological advances and information are needed in everyday life, but changes at the rumah gadang cause a shift in the existing customs structure.

The rumah gadang of the Minangkabau tribe, has great potential in storing socio-cultural assets of its people, therefore it is necessary to conduct more in-depth research about the changes that occur at rumah gadang, focusing on the problem at the entrance. Problems that need to be found in the answer are:

1. What changes occurred at the entrance to the rumah gadang?

2. What factors cause change?

\section{METHODOLOGY}

The research method is determined based on the research objectives to be achieved, then used naturalistic qualitative research methods. In qualitative research the essence is observing people in their environment, interacting, trying to understand the language and interpretation of people about the world around them. The study was conducted in a reasonable situation or in a natural setting. While the data collection method, is qualitative methods. Truth according to qualitative research here depends on the world of empirical reality and consensus in the scientific community. Naturalistic study is inductive, which is trying to seek and find a theory based on data collected.

\section{RESULTS OF ANALYSIS}

The entrance to rumah gadang, strongly supports the circulation of activities, the door as a liaison to carry out activities to enter or exit from a place that is affected by the occupants' activities. Technology, industry, contact with other cultures make residents of the rumah gadang make changes to activities and require different facilities compared to the initial facilities. Observations at the two rumah gadang indicate that there are changes at the entrance to rumah gadang.

\section{DISCUSSION}

The Gajah Maharam type of rumah gadang, the main door is different from the other types, which is behind the house. Opposite the main door there is a kitchen room, which is located separately from the rumah gadang. The meaning of the philosophy from the location of the main door behind and in front of this kitchen is that everyone who will enter the rumah gadang, especially mamak in charge of his niece's child, can find out if there is still something to be cooked to eat. If it turns out there is no one, then mamak can immediately find out and act to overcome the problem.

In the two rumah gadang observed, changes were seen in rumah gadang 1 , the main door was initially at the back of the rumah gadang (Fig. 1), the change that occurred was the main door was still behind the house, but there was an additional door before reaching the main door (Fig. 2). Addition is done as an additional security.
There are additional activities and needs of residents, making occupants need to add space behind the rumah gadang. Philosophically, the meaning of the entrance customs is maintained at this rumah gadang, because from the flow of circulation, even though it has to pass an additional door, users will still pass through the kitchen room before entering rumah gadang. But when viewed from the communal lifestyle adopted by Minangkabau people, the addition of this door has shifted to more individual/private (fig. 3)

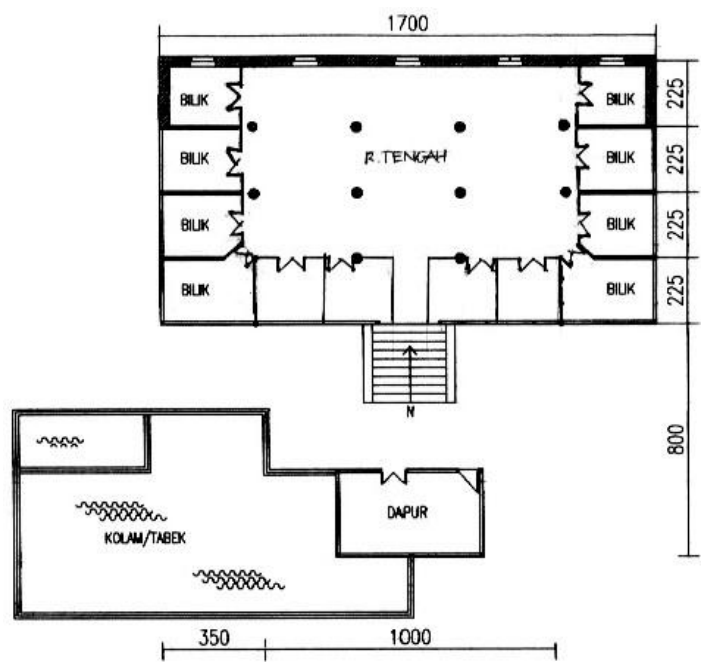

Figure. 1. Initial plan of rumah gadang 1

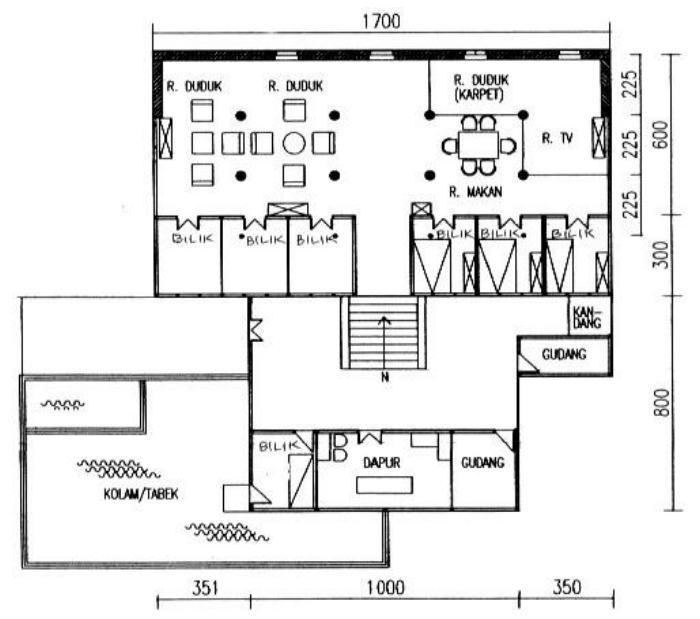

Figure 2. New plan of rumah gadang 1

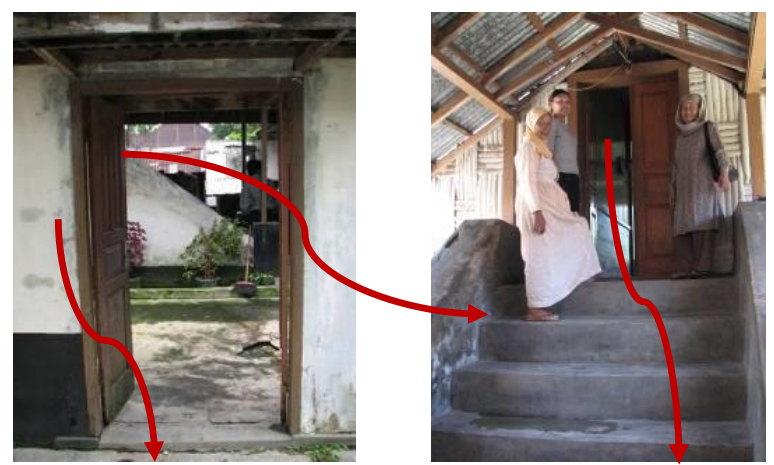

Additional doors

Figure. 3. Additional doors at the gadang house 1

The change in the location of the main entrance at the house 2 is originally in the back and now in front 
(Fig. 4), according to traditional philosophical meaning, the meaning of the location of the entrance is not the same. The meaning of the entrance to the rumah gadang is motivated by the difficult conditions of the time of war, where residents and surrounding communities need each other so that the consideration of the door location is emphasized on the efficiency of the function, users can more easily enter and exit the house from the main road. The driver of this change is the exogenous factor (from the outside) and the endogenous factor (from within) the occupant itself. The exogenous factor is, the needs that occur during the war, many people are lacking food and clothing, for this reason, a means is needed that can be a place to help among others and help the needs of the fighters as a means to gather and the need to protect from the weather and invaders. For that, to be more effective the location of the entrance which is generally behind, is changed to the front. Whereas endogenous factors arise, derived from the individual characteristics and desires of residents to help each other.

In both rumah gadang it is a relatively wellmaintained building. The economic level and educational background of the occupants are quite high, at least this exogenous and endogenous factor influences the occurrence of changes at the entrance of the rumah gadang, because every change that occurs must be balanced by the ability of the residents to finance the change and the desire to make changes, including influencing from outside (exogenous) when the occupants are studying.

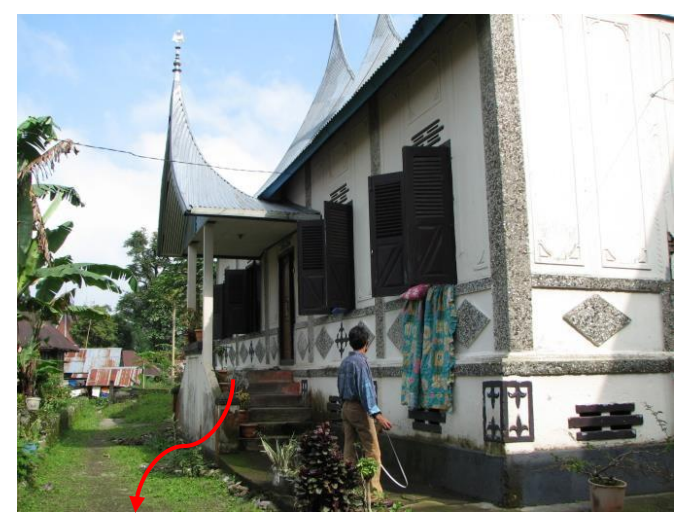

Tangga masuk ke rumah gadang

Fig. 4. Entrance at the front of the rumah gadang 2

\section{CONCLUSION}

Changes in rumah gadang Minangkabau are caused by a shift in public appreciation of the values of Minangkabau customs. Changes variations that occur are in the location of the entrance which was originally located on the back of the house to be changed into the front, This change is caused by a different perspective on the meaning of the entrance to Rumah Gadang. Functional aspects which are the main consideration on the new location of the door, are not in line with customary considerations. Different views are generally caused due to the way of life of modern society that is more concerned with safety, ease of purpose, circulation and comfort. Changes can be caused by: a. Exogenous factors, such as the dissemination of technological and information progress through various media, educational backgrounds, and economic levels. b. Endogenous factors: lifestyle, efficiency.

The findings obtained can be input for the general public and academics, in addressing the flow of information that is difficult to filter between negative and positive. Can be a guide, because from the results of the study it is known that the original / initial form and known variations in changes, exist as control over the causes that affect change.

Conservation of rumah gadang as a traditional Minangkabau house, as a preservation of the cultural values of the Minangkabau people will help tourism development efforts, so that it can help improve the economy of the local community.

Preservation, which basically does not forget local rules and customs, can be adjusted to achieve the purpose of a residential house, so that occupants remain comfortable even though simultaneously have to keep the preservation of customs rumah gadang.

\section{ACKNOWLEDGMENT}

Thank you to the Dean of the Faculty of Fine Arts and Design, Trisakti University and his staff for the assistance and facilities provided. As well as fellow lecturers who have provided useful suggestions.

\section{REFERENCES}

[1] Haryadi dan Setiawan, Arsitektur, Lingkungan dan Perilaku : Suatu Pengantar ke Teori, Metodologi dan Aplikasi, Direktorat Jenderal DIKTI, Depdikbud, 1995

[2] M.S, Amir, Tanya Jawab Adat Minangkabau, Jakarta : PT. Mutiara Sumber Widya, Cetakan kedua, 2003

[3] Navis, AA, Alam Terkembang Jadi Guru : Adat dan kebudayaan Minang kabau, Jakarta : PT. Temprint, cetakan kedua, 1986

[4] Prawitasari, Y. Mencari Sosok Perumahan Ideal di Abad XXI, Seminar sehari Perumahan Rakyat. Yogyakarta: Lustrum V Fakultas Psikologi UGM,1989.

[5] Sarlito, W. Ruang Minimun Yang Sehat, Lokakarya Habitat. Jakarta: Departemen Pekerjaan Umum RI,1989.

[6] Sajogyo, P, Sosiologi Pembangunan, Fakultas Pasca Sarjana IKIP Jakarta, bekerja sama dengan Badan Koordinasi Keluarga Berencana Nasional, Jakarta. 1985

[7] Yandri, MSi, Drs, Efi, cs, Nagari Dalam Perspektif Sejarah, Padang: Lentera 21, 2003. 